\title{
33. LEG 46 CRUISE SYNTHESIS: THE PETROLOGY, STRUCTURE, AND GEOLOGIC HISTORY AT SITE 396
}

\author{
R. James Kirkpatrick, ${ }^{1}$ Scripps Institution of Oceanography, La Jolla, California \\ and \\ The Leg 46 Scientific Party ${ }^{2}$
}

\section{INTRODUCTION}

Leg 46 was the third attempt by Glomar Challenger to drill a deep hole into oceanic crust near the Mid-Atlantic Ridge. Leg 37 had previously drilled two re-entry holes (at Sites 332 and 333 ) at about $37^{\circ} \mathrm{N}$ west of the ridge (Leg 37 Shipboard Scientific Party, 1977). Leg 45 had drilled one deep hole (Site 395 ) at about $22^{\circ} 45^{\prime} \mathrm{N}$ also west of the ridge (Leg 45 Shipboard Scientific Party, 1978). Leg 46 drilled one re-entry hole (Hole $396 \mathrm{~B}$ ) at $22^{\circ} 59.14^{\prime} \mathrm{N}, 43^{\circ} 30.90^{\prime} \mathrm{W}$, about $150 \mathrm{~km}$ east of the ridge. Leg 45 had previously drilled a pilot hole at this site.

These legs, together with Leg 49, which drilled a series of single bit holes along the length of the MAR from about $64^{\circ} \mathrm{N}$ to $36^{\circ} \mathrm{N}$, and Legs 51,52 , and 53 , which together drilled two deep holes in older crust at about $25^{\circ} \mathrm{N}, 68^{\circ} \mathrm{W}$, comprise two transects designed to examine the variation of the Atlantic oceanic crust in time and space. The longitudinal transect, Legs $37,45,46$, and 49 , was designed to look for differences in relatively young crust along the length of the ridge. The east-west traverse (Legs 45, 46, and 51, 52, and 53) was designed to examine the changes in crust generated in the same part of the ridge with age. The Leg 46 site (396), then, is the southern end of the longitudinal traverse and the eastern end of the east-west traverse.

The purpose of this paper is to summarize the conclusions of the authors who have contributed to the volume and to act as a guide to the papers. Some of these conclusions were reached aboard ship and will be found in the Hole 396B Site Chapter (Leg 46 Scientific Party). Others are based on

\footnotetext{
'Present address: Department of Geology, University of Illinois, Urbana, Illinois.

${ }^{2}$ Leonid Dmitriev, Institute of Geochemistry, Academy of Sciences of the USSR, Moscow W334, USSR. James Heirtzler, Woods Hole Oceanographic Institution, Woods Hole, Massachusetts. Drummond Matthews, Department of Geodesy and Geophysics, Cambridge University, Cambridge, England. Nikolai Petersen, LudwigMaximilians-Universität München, 8 München 2, Federal Republic of Germany. Jose Honnorez, Division of Marine Geology and Geophysics, Rosenstiel School of Marine and Atmospheric Science, Miami, Florida. Daniel Ohnenstetter, Laboratoire de Petrologie C.O. 140, 54.037 Nancy Cedex, France. Hiroaki Sato, Department of Earth Sciences, Kanazawa University, Ishikawa 920, Japan. Hans Schmincke, Institut für Mineralogie, Ruhr-Universität Bochum, D-463 Bochum, Federal Republic of Germany. Henry Dick, Department of Geology, Woods Hole Oceanographic Institution, Woods Hole, Massachusetts. Michael Dungan, NASA - Lyndon B. Johnson Space Center, Houston, Texas. Floyd N. Hodges, Department of Geology, Furman Uniersity, Greenville, South Carolina. Al Erickson, Department of Geology, University of Georgia, Athens, Georgia.
}

post-cruise work, and will be found in the individual contributions which make up the bulk of this volume. These papers will be referred to by the authors only and will not be included in the references listed.

Leg 46 drilled two holes at Site 396. Leg 45 had already drilled a single bit pilot hole (Hole 396) in the same sediment pond. Of the Leg 46 holes, 396A was a mudline test and $396 \mathrm{~B}$ was a multiple re-entry hole which penetrated to a total depth of 405.5 meters. Hole 396A penetrated only the very top of the sediment column and recovered only soupy nannofossil ooze. For Hole 396B most of the sediment column was washed to set casing for the re-entry cone, and most of the recovery was from the basaltic basement. The hole was lost in an apparently unconsolidated basaltic sand and gravel unit after penetrating 255 meters into basement. Leg 45 had previously cored the entire sediment column in Hole 396, as well as 125.5 meters into basement. The age of the oldest sediment is about 13 m.y. (Shipboard Scientific Party, 1978).

In many ways the results of Leg 46 are similar to the results of previous drilling and dredging in the Mid-Atlantic Ridge. Chemically and mineralogically the basalts are typical low potassium and titanium, light rare-earth element depleted mid-ocean ridge basalts. There are two types: a sparsely phyric (aphyric of some authors) low $\mathrm{CaO}$ and $\mathrm{Al}_{2} \mathrm{O}_{3}$ type and an olivine and plagioclase phyric high $\mathrm{CaO}$ and $\mathrm{Al}_{2} \mathrm{O}_{3}$ similar to the high and low alumina types of Miyashiro et al. (1969). Dmitriev has found that both types are very near the average MORB for all elements. Neither primitive $\mathrm{MgO}$ and $\mathrm{Cr}_{2} \mathrm{O}_{3}$ rich types or evolved iron and titanium rich types are present. The basalts can be divided into several stratigraphic units based on chemistry and petrography. They can also be divided into several units based on stable magnetic inclinations. As at other sites in the Atlantic these inclinations do not correspond to the inclination expected from the latitude of the site.

Some of the results of Leg 46, however, have not been anticipated by previous work. Previous concepts of the petrogenesis of MORB's have centered on the generation of a parental magma in the mantle and then fractional crystallization of this primitive magma in relatively shallow chambers beneath the spreading center to give the observed compositions. Detailed mineralogical, chemical, and experimental work on the Leg 46 samples have shown that this model is far too simple and that a more complicated process, probably involving mixing of primitive and differentiated compositions (Dungan et al.) must be occurring. Geochemically the Leg 45 and 46 basalts appear to have different ratios of incompatible trace elements (such 
as $\mathrm{Ta} / \mathrm{Th}$ ) than the basalts drilled on Leg 37 and recovered from the FAMOUS area (Bougault et al.). This would seem to imply that the mantle parental to be basalts is geochemically different in the two localities. Leg 46 was also the first leg to use downhole geophysical logging tools to obtain in situ physical properties in the oceanic crust. This data has shown that the densities, sonic velocities, and electrical resistivities are lower and the porosities higher than the values obtained on returned samples in the laboratory.

\section{STRATIGRAPHY}

As has been shown on Legs 37 and 45, one of the principal advantages of drilling the ocean crust rather than dredging samples is that with core it is possible to examine the volcanic stratigraphy and thereby learn more about the detailed history of the ocean crust and the processes which formed it. This is also true for Leg 46.

Basement stratigraphy in Hole 396B has been defined by lithology and petrography, chemistry (both bulk analyses and electron microprobe analyses of glasses), magnetic inclination, and physical properties (downhole logging). Figure 1 illustrates the units defined and some of the data used.

The hole was divided into eight lithologic units aboard ship. Detailed descriptions of these units are given in the Site Chapter. The upper two units are sparsely olivine and plagioclase phyric pillow sequences separated by $20 \mathrm{~cm}$ of lithified nannofossil ooze (lithographic limestone). Unit 3 is a sparsely olivine and plagioclase phyric flow or shallow sill. Lithologic Unit 4 is an abundantly plagioclase and olivine phyric pillow basalt sequence. Unit 5 is a basalt pillow breccia and hyaloclastite unit. Unit 6 is a basaltic sand and gravel unit. Unit 7 is an olivine and plagioclase phyric basalt pillow or pillow breccia unit. Unit 8 is again basaltic sand and gravel. Recovery in Units 5 to 8 was very poor, and the details of the sequence are not well known.

These units have been used in the Site Report and most of the individual contributions, although some of the authors have made some changes. Sato et al., have lumped Units 1 and 2 and 5, 6, 7, and 8. Schmincke et al., have defined the base of unit 5 at the bottom of Core 29 , rather than Core 26 , as in the original scheme. The recovery in this interval, however, is so poor that nonarbitrary boundaries are difficult to define. The original bottom of Unit 5 was defined on the basis of the downhole logging data, since it is the only continuous data available in this interval.

In general, the chemical units correspond to the lithologic units, although there are some differences in detail (Figure 1). Lithologic Units 1,2 , and 3 , together comprise chemical Unit A. This has been divided into three sub-units based on the shipboard chemical analyses. These sub-units differ primarily in their $\mathrm{TiO}_{2}$ contents (Figure 1) and do not correspond to the lithologic units. In particular the flow or shallow sill, lithologic Unit 3, is chemically similar to some of the overlying pillow basalts of lithologic Unit 2 . Lithologic Unit 4, the porphyritic pillow sequence, corresponds to chemical Unit $\mathrm{B}$, which has been divided into two sub-units, again based primarily on $\mathrm{TiO}_{2}$. Lithologic Units 5 and 6 correspond to chemical Unit C. Lithologic Units 7 and 8 correspond to chemical Unit D, although there is only one analysis in this interval and the piece analyzed could be a piece of Sub-unit $\mathrm{B}_{1}$ which fell down the hole.

Several minor modifications to these units have been proposed in the light of post-cruise work. Dungan et al. have lumped the sub-units of $B$ because they believe the variability within the two sub-units to be as large as the differences between them. The other authors, however, have continued to use $\mathrm{B}_{1}$ and $\mathrm{B}_{2}$. In addition, Flower et al., using electron-microprobe analyses of glasses from pillow rinds, have proposed that there is a boundary between liquid types similar to the $A_{2}-A_{3}$ boundary, in Section 14-2. The glass analyses of Sato et al., and Dungan et al., however, are consistent with the boundary between liquid types being at the original $\mathrm{A}_{2}-\mathrm{A}_{3}$ boundary.

Four units were defined using the stable magnetic inclination data (Figure 1). The only magnetic unit boundary that does not correspond to a major lithologic and chemical break is the one between Units I and II.

The meaning of the differences between these different units has been a major topic of discussion in this volume and will be summarized in the rest of this article. What we can say right now, though, is that in this vertical section through the upper part of the oceanic crust there are intervals which differ significantly in their petrographic, chemical, and magnetic properties. Within the broad spectrum of igneous rock found in the earth's crust the variation is not great, but it is just this variation that will allow us to examine the processes of petrogenesis, volcanism, and tectonism which occur during the generation of the oceanic crust at spreading centers and the subsequent alteration which occurs as the crust ages.

\section{MINERALOGY}

Mineralogically the Leg 46 basalts are typical MORB's. The primary groundmass phases are always olivine, plagioclase, augitic clinopyroxene, titanomagnetite, and in the thicker flow or sill of lithologic Unit 3, ilmenite. Sulfide spherules are also ubiquitous. Phenocryst phases are olivine and plagioclase. The only peculiarity is the almost total lack of clinopyroxene phenocrysts, which are common in most other porphyritic ocean ridge basalts. Only two have been described in the hundreds of thin sections examined by the contributors to this volume (Sato et al.; Flower et al.). Papers in this volume discussing various aspects of the mineralogy include those of Dungan et al.; Sato et al.; Mevel et al.; Flower et al.; Kirkpatrick; Hodges; and Dick).

The groundmass in both the sparsely phyric and porphyritic pillow basalts is similar. From the outside of the pillows inward there are gradational zones of glass, spherulites, and microlites similar to those described by Bryan (1972). The details of the textural variations in the Leg 46 pillows are discussed by Kirkpatrick. The morphology of the groundmass olivine is usually skeletal and many have the lantern shape described by Bryan (1972). The plagioclase morphology ranges from spherulitic to lath-shaped. The most calcic groundmass plagioclase is about $\mathrm{An}_{70}$ in all units, and some grains are as sodic as An50. The pyroxene morphology ranges from spherulitic to dendritic. They are all augitic in composition. Titanomagnetite is uniformly skeletal and less than $10 \mu \mathrm{m}$ in size.

The groundmass mineralogy of the flow or sill in lithologic Unit 3 is similar to the pillow basalts except that it contains ilmenite in addition to the other groundmass phases and has 


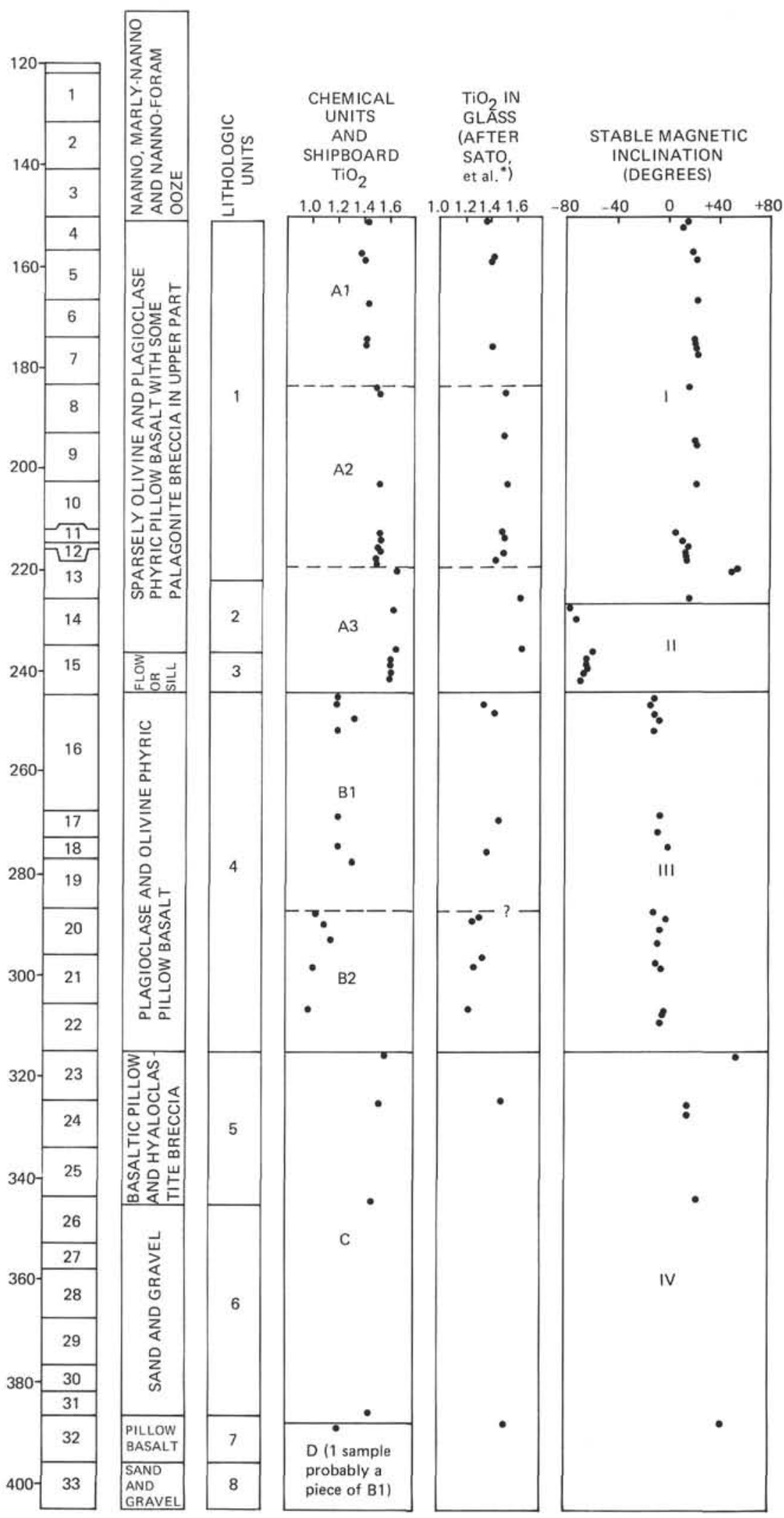

Figure 1. Stratigraphy of the drilled section in Hole 396B. Definition of lithological, chemical, and physical properties units is discussed in the text. 
less residual glass. The mineral compositions are also quite similar, although the texture is mostly intergranular and considerably coarser.

In the sparsely phyric units (chemical Units A and C) total phenocrysts plus microphenocrysts (less than about $0.1 \mathrm{~mm}$ ) are less than 1 per cent, with olivine slightly more abundant than plagioclase. The phenocrysts are usually rounded, while the microphenocrysts are mostly skeletal or euhedral. In chemical Unit A the olivine microphenocrysts range from $\mathrm{Fo}_{84}$ to $\mathrm{Fo}_{86}$ and become progressively less magnesian downward from Unit $A_{1}$ to Unit $A_{3}$, corresponding to the progressively less magnesian bulk compositions. The olivine microphenocrysts in chemical unit $\mathrm{C}$ are similar to those in Unit $\mathrm{A}_{1}$, about Fo86. The olivine phenocrysts in this unit are as magnesian as Fo8s. The plagioclase microphenocrysts in Units $A_{1}$ and $A_{2}$ range from $A_{65}$ to $A_{68}$. Those in $A_{3}$ are more sodic, An61-65. The larger, rounded, phenocrysts are more calcic in all three A sub-units, ranging from $\mathrm{An}_{74}$ to An86. In chemical Unit $C$ the microphenocrysts are An71-74, and the phenocrysts as calcic as An84.

In the porphyritic rocks of chemical Unit B the relative phenocryst compositions are much the same as in the sparsely phyric units, although the phenocrysts are much more abundant (and also better studied). The olivine phenocrysts are rounded, skeletal, or euhedral, and range from Foss to about Fo90. Most of the grains are normally zoned, with the most magnesian compositions in the centers. Some, however, are reversely zoned. The microphenocrysts are less magnesian, from Fo83 to Fo86.5, and define a partition coefficient of about 0.27 assuming all iron as $\mathrm{FeO}$ or about 0.33 assuming 10 per cent of the iron as $\mathrm{Fe}_{2} \mathrm{O}_{3}$.

The situation with the plagioclase phenocrysts is similar. The microphenocrysts and phenocryst rims are An69-72, while the cores of the phenocrysts range up to An85. As with the olivine, most of the plagioclase phenocrysts are normally zoned. Others, though, are reversely zoned with rim compositions as calcic as $\mathrm{An}_{84}$, others are essentially unzoned or are complexly zoned. Many have rims with compositions of about An70-72, similar to the most calcic groundmass and microphenocryst grains.

The results of 1-atmosphere gas mixing equilibrium experiments (Dungan et al., Fukuyama and Hamuro) indicate that the most magnesian olivine phenocrysts and the most calcic plagioclase phenocrysts in both the sparsely phyric and porphyritic basalts cannot have grown from liquids with either the present bulk compositions or the present glass compositions. For sparsely phyric samples from Core 7 (chemical Unit $A_{1}$ ) at reasonable oxygen fugacities (about $\log \mathrm{f}_{02}=10^{-8}$ ) the liquidus olivine is about $\mathrm{Fo}_{87}$ and the liquidus plagioclase is about $\mathrm{An}_{74}$ or a little more. For a sample from the sparsely phyric flow or sill the liquidus olivine is about Fo84. This compares to Fo86 olivine phenocrysts and Ans6 plagioclase phenocrysts found in the sparsely phyric units. For porphyritic samples from Core 22 (chemical Unit $\mathrm{B}_{2}$ ) the experimental liquidus olivine is about $\mathrm{Fo}_{87}$ and the liquidus plagioclase is about An84. This compares to olivine phenocrysts as magnesian as Fo90 and plagioclase phenocrysts as calcic as An85.

\section{CHEMISTRY AND PETROGENESIS}

Chemically the Leg 46 basalts are all typical ocean ridge tholeiites. They are low in $\mathrm{K}_{2} \mathrm{O}$ and $\mathrm{TiO}_{2}$ and are generally similar to many samples from Legs 37 and 45 (Legs 37 and 45 Shipboard Scientific Parties, 1977 and 1978). Table 1 lists average chemical compositions for each sub-unit as determined from the shipboard analyses.

These are two main chemical types: a low $\mathrm{CaO}$ and $\mathrm{Al}_{2} \mathrm{O}_{3}$ type which corresponds to the sparsely phyric basalts (chemical Units $\mathrm{A}$ and $\mathrm{C}$ ) and a high $\mathrm{CaO}$ and $\mathrm{Al}_{2} \mathrm{O}_{3}$ type which corresponds to the porphyritic basalts (chemical Unit B). Overall both types are very close in composition to the average mid-ocean ridge basalt (Dmitriev). There are no primitive high $\mathrm{MgO} / \mathrm{MgO}+\mathrm{FeO}$ and high $\mathrm{Ni}$ types like the most primitive samples from the FAMOUS area (Bryan and Moore, 1977) or from DSDP Legs 2 and 3 (Frey et al., 1976). Neither are there any iron- and titanium-rich basalts like those found on the East Pacific Rise (Clague and Bunch, 1976).

In terms of their trace elements the Leg 46 basalts are also very similar to typical ocean ridge basalts. They are low in the low partition coefficient magmatophile trace elements such as $\mathrm{Zr}$, Hf, and Ta (Bougault et al., Dungan et al.). Stratigraphic units defined on the basis of these elements are the same as those defined using the major elements (Bougault et al.). Although the amounts are different in each unit, the ratios are the same for all except chemical unit $\mathrm{C}$. These ratios, particularly those involving thorium, are similar to those from Leg 45 samples, but significantly different than those from Leg 37 and the FAMOUS area. $\mathrm{Zr} / \mathrm{TiO}_{2}$, on the other hand, is the same in the basalts from all three Atlantic crustal legs.

The Leg 46 basalts also have light depleted REE patterns similar to those from Leg 46 and most of those from Leg 37. Leg 37 did, however, have some with essentially flat or slightly light enriched REE patterns (Schilling et al., 1977; Puchelt et al., 1977). All of the aphyric or sparsely phyric samples from Legs 45 and 46, except for those from chemical Unit C of Leg 46 have similar chondrite normalized abundances and patterns. Unit $\mathrm{C}$ has a slightly higher $\mathrm{La} / \mathrm{Sm}$ ratio. The porphyritic basalts from both legs have similar patterns to the sparsely phyric basalts, but lower overall abundances. The sparsely phyric units exhibit a slight negative europium anomaly in the data of Dungan et al. and no europium anomaly from the data of Emmermann and Puchelt. The porphyritic basalts show no significant europium anomaly in either set of data.

For the most part the contributors to this volume assumed or concluded that the basalts from Hole 396 are relatively differentiated and were derived from a more primitive magma richer in $\mathrm{MgO}$ and $\mathrm{Ni}$ and lower in $\mathrm{TiO}_{2}$, the rare earth elements, $\mathrm{P}_{2} \mathrm{O}_{5}$, and the incompatible trace elements. Sato et al. concluded on the basis of major element compositions that Unit $\mathrm{A}_{2}$ could be derived from Unit $\mathrm{A}_{1}$ and Unit $B_{1}$ derived from Unit $B_{2}$ by the fractionation of plagioclase, clinopyroxene, and minor olivine. Their calculations show that Units $\mathrm{A}_{3}$ and $\mathrm{C}$ cannot be derived from any unit cored. Similar calculations by Kirkpatrick showed that neither the variation within or between the units is well described by fractionation of the low-pressure liquidus phases, olivine and plagioclase. Clinopyroxene appears to be a necessary fractionating phase if ordinary crystal-liquid fractionation is to account for the variation in the bulk compositions. This is at odds with the observation that clinopyroxene phenocrysts are extremely rare and the 
TABLE 1

Average Chemical Analyses of Magmatic Units, Hole 396B

\begin{tabular}{lrrrrrr}
\hline $\begin{array}{c}\text { Major Elements } \\
\text { (wt \%) }\end{array}$ & \multicolumn{7}{c}{ C1 } & \multicolumn{1}{c}{$\mathrm{A} 2$} & \multicolumn{1}{c}{$\mathrm{A} 3$} & \multicolumn{1}{c}{$\mathrm{B} 1$} & \multicolumn{1}{c}{$\mathrm{B} 2$} & $\mathrm{C}$ \\
\hline $\mathrm{SiO}_{2}$ & 49.69 & 50.03 & 49.94 & 49.67 & 49.63 & 49.10 \\
$\mathrm{Al}_{2} \mathrm{O}_{3}$ & 15.59 & 15.29 & 15.19 & 16.91 & 17.66 & 15.86 \\
$\mathrm{Fe}_{2} \mathrm{O}_{3}$ & 10.15 & 10.53 & 11.00 & 9.45 & 8.73 & 10.44 \\
$\mathrm{MgO}$ & 7.93 & 7.72 & 7.75 & 7.78 & 7.84 & 7.76 \\
$\mathrm{CaO}$ & 11.83 & 11.66 & 11.12 & 12.34 & 12.66 & 11.51 \\
$\mathrm{Na}_{2} \mathrm{O}$ & 2.63 & 2.62 & 2.79 & 2.45 & 2.43 & 2.66 \\
$\mathrm{~K}_{2} \mathrm{O}$ & 0.24 & 0.25 & 0.23 & 0.22 & 0.20 & 0.27 \\
$\mathrm{TiO}$ & 1.41 & 1.53 & 1.64 & 1.23 & 1.06 & 1.51 \\
$\mathrm{Total}$ & 99.47 & 99.63 & 99.62 & 100.05 & 100.21 & 99.11 \\
& & & & & & \\
$\mathrm{Trace} \mathrm{Elements}$ & & & & & & \\
$(\mathrm{ppm})$ & & & & & & \\
& 347 & 305 & 277 & 332 & 351 & 349 \\
$\mathrm{Cr}$ & 136 & 132 & 138 & 133 & 142 & 133 \\
$\mathrm{Ni}$ & 128 & 139 & 145 & 133 & 136 & 157 \\
$\mathrm{Sr}$ & 94 & 101 & 120 & 80 & 69 & 104 \\
$\mathrm{Zr}$ & & & & & & \\
\hline
\end{tabular}

experimental work which indicates that clinopyroxene does not begin to crystallize until at least $40^{\circ} \mathrm{C}$ below the liquidus. Sato et al. believe that some high-pressure fractionation must have occurred.

Flower et al. believe that each chemical sub-unit is a separate magma batch not related to the others, but that they most likely were derived by taping different fractions of a larger magma body differentiating under closed conditions.

Puchelt and Emmermann believe that the lack of variation in the shape of the REE curves and the lack of the europium anomaly imply that there has been no large-scale differentiation after the magmas were generated. Bougault et al., on the other hand, conclude that the high and low partition coefficient trace elements imply "a substantial history of differentiation.",

Dungan et al., however, conclude that mixing of consanguineous primitive and differentiated magmas can account for more of the mineralogical and chemical features of at least the porphyritic basalts than can simple crystal-liquid differentiation. They believe that this process can account for the non-equilibrium compositions of the olivine phenocrysts, the decreasing $\mathrm{CaO} / \mathrm{Al}_{2} \mathrm{O}_{3}$ with increasing $\mathrm{TiO}_{2}$ (which is the main reason for calling on clinopyroxene fractionation in differentiation models), and the primitive composition $(\mathrm{MgO} / \mathrm{MgO}+\mathrm{FeO}$ greater than $0.70, \mathrm{CaO} / \mathrm{Al}_{2} \mathrm{O}_{3}$ greater than $0.85, \mathrm{TiO}_{2}$ less than 0.85 ) of the glass inclusions in the olivine and plagioclase phenocrysts. Their calculations, too, show that the compositions of the chemical units and sub-units cannot be derived from each other by olivine and plagioclase fractionation.

Dick and Bryan stress the role of a magma chamber or chambers in the evolution of Hole 396B basalts and agree with Dungan et al. that magma mixing may have played an important role. They feel, however, that eruption from different parts of a magma chamber zoned with respect to liquid composition and phenocryst proportions can account for most of the variations seen within individual Hole 396B pillow basalt units. This is due to gravitational sorting of phenocrysts and incomplete mixing of magmas in the chamber on the time scale of the eruptive cycle. They suggest a model of cyclic volcanism largely controlled by intermittent earthquakes and rifting episodes along the ridge axis with long hiatuses during which the weathering and sedimentation occurred at the tops of the various units. Differences between the major pillow basalt units are thought to be the consequence of random combinations of fractional crystallization and introduction of new magma, or the formation of a new magma chamber between eruptive episodes.

It appears, then, that the contributors to this volume are substantially in agreement with the shipboard classification and stratigraphic divisions of the basalts from Hole 396B. For the most part they also agree that the original magma was derived from a REE and LIL depleted mantle and that the chemical units and sub-units cannot be derived from one another by differentiation of olivine and plagioclase, the overwhelmingly dominant phenocryst phases. There is considerable disagreement as to what the processes that caused the compositional variations were. Because of the non-equilibrium phenocryst compositions, the complex zoning of the phenocrysts, the inability of plagioclase and olivine differentiation to account for the observed bulk compositions, and other data, however, it seems that this process must be more complex than just crystal-liquid differentiation.

\section{ORIGIN OF THE CLASTIC INTERVAL}

The clastic interval, lithologic Units 5 to 8 , is a unique and enigmatic interval. It is complex, containing carbonate-cemented palagonite breccia overlying unconsolidated basaltic sand, basaltic sandstone, pillow breccia, and possibly pillow basalt. The investigation of the interval has been hampered by very poor recovery (average about 7 per cent). Although small amounts of clastic material are commonly seen in photographs of the ocean floor, whether this interval is significant to understanding the oceanic crust or just a minor feature which happened to be drilled will require more drilling to determine. Dick et al. and Schmincke et al. have investigated this sequence in detail.

The most controversy has centered around the unconsolidated basaltic sand and gravel (hyaloclastite) recovered in Cores 30 and 33. Questions about this material include: is it real or a drilling artifact? If it is real, how was it formed and what is the source of the material? and why is the glass so fresh?

Both Schmincke et al. and Dick et al. conclude that at least some of the unconsolidated material is primary and not due to drilling. Evidence for this includes the presence of weakly cemented basaltic sandstones with glassy and crystalline basalt grains similar to the loose material, the extremely high drilling rate for Core 30 , the high porosity, the low sonic velocities, densities, and electrical resistivities obtained from the downhole logs, the high proportion of glass to crystalline basalt, and the presence of well-cemented glassy fragmental material above it. Schmincke et al. conclude that the material in both Cores 30 and 33 are primary, while Dick et al. conclude that the material in Core 30 is primary but that in Core 33 is drilling debris mixed with unconsolidated material which caved in from the Core 30 interval. Evidence for this is 
that the drilling rates for Core 33 were much lower than for Core 30 . Both sets of authors admit that some cuttings may be mixed with the primary material.

Dick et al. and Schmincke et al. also agree that the original breakage of the material occurred during the eruption process and not by process associated with faulting, mass wasting, or erosion. Evidence for this includes the high proportion of glassy fragments, the limited compositional range of the glasses, and the angular morphology of the grains. Explosive volcanism was probably not involved because of the large depth of eruption as evidenced by the lack of vesicles in the basalts. Whether the fragmentation was due to thermal quenching upon eruption or breakage of pillow rinds during flowage is not clear.

The thickness of the interval (at least $90 \mathrm{~m}$ ) and the high angularity of the grains compel both sets of authors to conclude that accumulation took place by current action near the original source of the clasts and probably in a depression on the sea floor.

Both authors also believe that the extremely unaltered state of the glass fragments and the small amount of authigenic cementing material require that the interval be isolated from circulating ground water for most of its history. How a porous and permeable interval like this could be isolated when the overlying pillow basalts show evidence of significant interaction with circulating water is a major problem. Both Schmincke et al. and Hodges suggest that this isolation may have occurred by palagonitization of the upper part of the interval, as in Cores 23 and 24 , resulting in a drastic reduction of the permeability of the outside of the unit, isolating the inside. Rapid sedimentation may also have been a factor. Supporting evidence for the isolation of this interval comes from the downhole temperature data (Erickson and Hyndman), which indicates that cold seawater was flowing down the hole and out into the rocks below. Erickson and Hyndman believe that this may imply that the hole penetrated a previously hydrologically isolated interval.

\section{ALTERATION}

It appears that all the basalts recovered on Leg 46 except for the unaltered glassy material have undergone some low-temperature alteration and that many of them have been extensively altered. No evidence of high-temperature alteration has been found and the grade of alteration appears to be the same throughout the hole. This is the same situation found in the holes drilled on both Legs 37 and 45 (Robinson et al., 1977; Lawrence and Drever, 1978).

The alteration of the Leg 46 basalts has been discussed in two papers by Honnorez et al. and also briefly touched upon by several of the petrology papers; Muehlenbachs and Hodges and Hoernes and Friedrichsen have examined the effect of alteration on the oxygen isotope composition of the basalts.

Honnorez et al. have found that all the rocks they examined were oxidized, but that those which are brown in color are more extensively oxidized and have undergone extensive chemical changes. In the gray, fresh appearing rocks the oxidation ratio $\left(\mathrm{Fe}^{3+} / \mathrm{Fe}\right.$ total) ranges up to 0.34 , compared to a theoretical unaltered value of about 0.14 , and the titanomagnetite has been altered to titanomaghemite. Most of the olivine in these samples is still fresh. In the brown, more altered appearing samples the oxidation ratio is at least $0.56, \mathrm{H}_{2} \mathrm{O}^{+}$is higher, most of the opaque minerals are gone, and the olivine is altered. Compared to adjacent fresher (gray) samples $\mathrm{MgO}$ in the altered rocks is considerably lower and $\mathrm{SiO}_{2}$ is somewhat lower. $\mathrm{FeO}^{*}, \mathrm{Al}_{2} \mathrm{O}_{3}, \mathrm{TiO}_{2}$, $\mathrm{Na}_{2} \mathrm{O}$, and $\mathrm{CaO}$ have not changed much. $\mathrm{K}_{2} \mathrm{O}$ has increased slightly in most altered samples, but has remained unchanged in some. The $\mathrm{P}_{2} \mathrm{O}_{5}$ content of the brown (more oxidized) zones is nearly twice that of the gray zones or of the fresh glass. P was probably scavenged from seawater during the formation of Fe hydroxides. The stronger (brown) alteration is localized near cracks and other exposed surfaces and generally surrounds patches of relatively fresh (gray) rock.

Two kinds of boundaries are observed between the gray and brown portions of individual pieces. Both are less than 2 to $3 \mathrm{~mm}$ thick and contain unaltered primary crystalline phases. The "'black fronts"' have vesicles and vugs filled by dark green and brown to white clay minerals. In the "light fronts" the interstitial groundmass material is lighter and the vugs are not filled. The veins around which brown oxidation zones are localized in the pillow basalts have generally been filled either sequentially (from walls to centers) by various smectite, Fe-Mn oxides, euhedral phillipsite and calcite, or by an intimate mixture of these phases.

Analyses of oxygen isotopes (Muehlenbachs and Hodges, and Hoernes and Friedrichsen) and hydrogen isotopes (Hoernes and Friedrichsen) in the Leg 46 basalts show that all samples analyzed have undergone some low-temperature alteration and an increase in the whole rock $\delta \mathrm{O}^{18}$ value due to smectite formation. The carbonate analyzed also formed at low temperature. Little evidence of high-temperature alteration has been found, and data for separated olivine and plagioclase phenocrysts indicate that they have exchanged oxygen to a much lower extent than phenocrysts in Legs 37 and 45 basalt.

The data for samples analyzed for oxygen isotopes from the clastic unit (lithologic Units 5 to 8) indicate that they have undergone much less low-temperature exchange than the overlying pillow basalts. This is in agreement with the conclusion that the clastic interval has been isolated from circulating ground water.

\section{PALEOMAGNETISM AND ROCK MAGNETISM}

As discussed above, the magnetic stratigraphy of Hole $396 \mathrm{~B}$ is complex, with four identifiable intervals of relatively uniform magnetic inclination. Petersen has found that all of the boundaries between these units, except for the one between magnetic Units I and II, correspond to major lithologic and chemical boundaries. This may imply some tectonic tilting. The stable magnetic inclinations of all units except for unit II, which includes all of lithologic Unit 3 and part of Unit 2, are less than the theoretical central dipole inclination of $40.3^{\circ}$. This, along with the presence of intervals with distinct magnetic inclinations, is very much the same as in the holes drilled on Legs 37 and 45 . Because of the presence of these units and their relatively low inclinations, the intensity of remanent magnetization integrated over the entire hole cannot account for the amplitude of the marine magnetic anomaly observed over the site (Purdy et al., 1978).

Ellwood and Watkins, as part of a long-term study of DSDP basalts, examined the anisotropy of magnetic 
susceptibility. They concluded that all their samples except those from lithologic Unit 3, the flow or sill, are extrusive in origin. This agrees with the observation that all the basalts except those from Unit 3 are pillow basalts.

Smith, also as part of a long-term study, investigated the magnetic viscosity - the ratio of the viscous remanent magnetization to the stable natural remanent magnetization. Smith concluded that the viscosities are generally very low, but slightly higher than the youngest fresh basalts from the FAMOUS area.

Honnorez et al. studied the variation in chemistry, mineralogy, and magnetic properties of associated altered (brown) and relatively fresh (gray) basalts. They concluded that even in the least-oxidized samples the titanomagnetite has undergone a low-temperature alteration to titanomaghemite, while in the more altered samples only relicts of the opaque phases remain. The Curie temperatures are in the range $200^{\circ}$ to $400^{\circ} \mathrm{C}$, compared to about $110^{\circ} \mathrm{C}$ for fresh titanomagnetite. The Curie temperatures are slightly higher and the saturation magnetization lower in the more oxidized samples compared to adjacent relatively fresh samples.

\section{PHYSICAL PROPERTIES AND THE STATE OF THE OCEANIC CRUST}

Leg 46 was the first leg on which downhole logging tools, aside from temperature probes, were used to obtain in situ physical property data. These data are the first such data ever obtained in the oceanic crust, and combined with the laboratory physical properties data and the downhole temperature data (Erickson and Hyndman; Hyndman et al.; Matthews; Kirkpatrick) have given us a much clearer picture of the physical state of layer 2 . The logging tools used include compensated sonic velocity, gamma-gamma density, neutron porosity, electrical resistivity, and natural gamma ray activity. Figure 1 illustrates the density data.

The major conclusion of this work is that for the relatively young crust at Site 396 (about 13 m.y.) the true in situ densities, sonic velocities, and electrical resistivities are significantly lower and the porosities significantly higher than the same values measured in the laboratory on returned samples (Kirkpatrick). Typical in situ values for the density in a pillow sequence (Figure 1) are about $2.5 \mathrm{~g} / \mathrm{cm}^{3}$, while laboratory values are typically 2.7 to $2.9 \mathrm{~g} / \mathrm{cm}^{3}$ for the pillow samples. Similar differences are observed for sonic velocity, electrical resistivity, and porosity.

These differences do not appear to be due to the drilling process because the electrical resistivities are the same close to the hole where most of the tools measure and up to about 2 meters from the hole.

This implies that at least in the pillow sequences logged there is significant void space distributed on a scale larger than about $6 \mathrm{~cm}$ (the diameter of the core) and less than about a meter, which is about the scale the tools measure over. It also agrees with the recovery of the basalt as pieces averaging about $10-13 \mathrm{~cm}$ long which often cannot be fit back together.
This picture is very similar to that developed by Hyndman and Drury (1976) for the holes on Leg 37 using drilling rates, laboratory physical properties, per cent recovery, and the nature of the core material. There does not appear, however, to be the downward increase in the per cent of solid basalts, sonic velocity, and other related properties that Hyndman and Drury (1976) interpreted in 332B. Because of the clastic interval (lithologic Units 5 to 8 ) there even seems to be a decrease. Hole 396B only penetrated about 255 meters of crust compared to 582 meters for Hole 332B, and these changes are certainly present at greater depths.

\section{REFERENCES}

Bryan, W.B., 1972. Morphology of quench crystals in submarine basalts, J. Geophys. Res., v. 77, p. 5812-5819.

Bryan, W.B. and Moore, J.G., 1977. Compositional variations of young basalts in the Mid-Atlantic Ridge rift valley near lat $36^{\circ} 49^{\prime}$ N, Geol. Soc. Am. Bull., v. 88, p. 556-570.

Clague, D.A., and Bunch, T.E., 1976. Formation of ferrobasalt at east Pacific mid-ocean spreading centers, J. Geophys. Res., v. 81 , p. $4247-4256$.

Frey, F.A., Bryan, W.B., and Thompson, G., 1974. Atlantic Ocean floor: geochemistry and petrology of basalts from Legs 2 and 3 of the Deep Sea Drilling Project, J. Geophys. Res., v. 79, p. 5507-5527.

Hyndman, R.D. and Drury, M.J., 1976. The physical properties of oceanic basement rocks from deep drilling on the Mid-Atlantic Ridge, J. Geophys. Res., v. 81, p. 4042-4052.

Lawrence, J.R., and Drever, J.J., 1978. Low temperature alteration of basalts dominates at Site 395. In Melson, W., Rabinowitz, P.D., et al., Initial Reports of the Deep Sea Drilling Project, v. 45: Washington (U.S. Government Printing Office).

Miyashiro, A., Shido, F. and Ewing, M., 1969. Diversity and origin of abyssal tholeiite from the Mid-Atlantic Ridge near $24^{\circ}$ and $30^{\circ}$ north latitude, Contrib. Mineral. Petrol., v. 24, p. 7-29.

Puchelt, H., Emmermann, R. and Srivastava, R.K., 1977. Rare earth and other trace elements in basalts from the Mid-Atlantic Ridge, $36^{\circ} \mathrm{N}$, DSDP Leg 37. In Aumento, F., Melson, W.G., et al., Initial Reports of the Deep Sea Drilling Project., v. 37: Washington (U.S. Government Printing Office), p. 581-590.

Purdy G.M., Rabinowitz, P.D. and Schouten, H., 1978. The Mid-Atlantic Ridge at $23^{\circ} \mathrm{N}$; Bathymetry and Magnetics. In Melson, W., Rabinowitz, P.D., et al., Initial Reports of the Deep Sea Drilling Project, v. 45: Washington (U.S. Government Printing Office).

Robinson, P.T., Flower, M.J.F., Schmincke, H.U. Ohnmacht, W., 1977. Low temperature alteration of oceanic basalts, DSDP Leg 37. In Aumento, F., Melson, W.G., et al., Initial Reports of the Deep Sea Drilling Project, v. 37: Washington (U.S. Government Printing Office), p. 775-794.

Schilling, J.C., Kingsley, R. and Bergeron, M., 1977. Rare earth abundances in DSDP Sites 332, 334, and 335. In Aumento, F., Melson, W.G., et al., Initial Reports of the Deep Sea Drilling Project, v. 37: Washington (U.S. Government Printing Office), p. 59-598.

Shipboard Scientific Party, Leg 37. In Aumento, F., Melson, W.G., et al.,Initial Reports of the Deep Sea Drilling Project, v. 37: Washington (U.S. Government Printing Office).

Shipboard Scientific Party, Leg 45, Site 396. In Melson, W. and Rabinowitz, P., et al., Initial Reports of the Deep Sea Drilling Project, v. 45: Washington (U.S. Government Printing Office). 